\title{
Liposome-incorporated Grb2 antisense oligodeoxynucleotide increases the survival of mice bearing $b c r$-abl-positive leukemia xenografts
}

\author{
ANA M. TARI ${ }^{1}$, YOLANDA GUTIÉRREZ-PUENTE ${ }^{1,5}$, GIUSEPPE MONACO ${ }^{2}$, CLIFTON STEPHENS $^{3}$, TONG SUN $^{4}$, \\ MICHAEL ROSENBLUM ${ }^{1}$, JOHN BELMONT ${ }^{2}$, RALPH ARLINGHAUS ${ }^{4}$ and GABRIEL LOPEZ-BERESTEIN ${ }^{1}$ \\ ${ }^{1}$ Department of Experimental Therapeutics, The University of Texas M.D. Anderson Cancer Center; ${ }^{2}$ Department of \\ Molecular and Human Genetics, Baylor College of Medicine; Departments of ${ }^{3}$ Veterinary Medicine and Surgery, and \\ ${ }^{4}$ Molecular Pathology, The University of Texas M.D. Anderson Cancer Center, Houston, TX, USA; ${ }^{5}$ Departamento de \\ Quimica, Facultad de Ciencias Biológicas, Universidad Autónoma de Nuevo León, Monterrey, NL, Mexico
}

Received May 18,2007; Accepted July 16, 2007

\begin{abstract}
We previously demonstrated that liposomeincorporated antisense oligodeoxynucleotide specific for the grb2 mRNA (L-Grb2) inhibited Grb2 protein expression and the proliferation of $b c r-a b l$-positive leukemia cell lines. To determine whether L-Grb2 has the potential of being a therapeutic modality against $b c r$-abl-positive leukemia, we studied the tissue distribution of L-Grb2 in normal mice before studying its effects in mice bearing $b c r$-abl-positive leukemia xenografts. L-Grb2 was widely distributed in the body. The highest tissue concentrations of L-Grb2 were found in the spleen and liver, which are the organs where the tumor mass of $b c r$-abl-positive leukemia is mainly found. At $4 \mathrm{~h}$ postinjection, the amount of L-Grb2 detected per $g$ of tissue was $64 \mu \mathrm{g}$ in spleen and $50 \mu \mathrm{g}$ in liver. Intravenous injection of bcr-abl-positive 32D mouse leukemia cells into radiated NOD/ scid mice caused a lethal leukemia syndrome; we determined whether L-Grb2 could prolong the survival of mice bearing such xenografts. One day after leukemia cell inoculation, mice received twice weekly intravenous injections of L-Grb2. At an injection dose of $15 \mathrm{mg}$ of L-Grb2 per $\mathrm{kg}$ of mouse body weight, $80 \%$ of mice treated with L-Grb2 survived to 48 days
\end{abstract}

Correspondence to: Dr Ana Tari, Department of Experimental Therapeutics, Unit 422, The University of Texas M.D. Anderson Cancer Center, 1515 Holcombe Boulevard, Houston, TX 77030, USA

E-mail: atari@mdanderson.org

Abbreviations: BUN, blood urea nitrogen; DOPC, dioleoylphosphatidylcholine; Grb2, growth receptor bound protein-2; ICR, Institute for Cancer Research; L-Grb2, liposome-incorporated Grb2 antisense; oligo, oligodeoxynucleotide; RBC, red blood cells; SGOT, serum glutamic-oxaloacetic transaminase; $\mathrm{SH}$ 2, Src homology 2; SH3, Src homology 3; WBC, white blood cells

Key words: Grb2, bcr-abl, antisense oligodeoxynucleotide (end of study) whereas $0 \%$ of mice treated with the same dose of liposomal control oligonucleotide survived; the mean survival duration of these groups was 44 and 20 days, respectively. Our data indicate that L-Grb2 prolonged the survival of mice bearing $b c r$-abl-positive leukemia xenografts. L-Grb2 may be used as a novel cancer therapeutic modality.

\section{Introduction}

Growth factor receptor bound protein-2 (Grb2) is an adaptor protein that is well conserved among numerous species. Grb2 consists of one Src homology 2 (SH2) domain flanked by two Src homology 3 (SH3) domains (1-4). The main function of Grb2 is to link activated tyrosine kinases to Ras activation (5-7). Grb2 uses its SH2 domain to bind to phosphotyrosine residues in activated tyrosine kinases $(3,4,8-11)$ and uses its $\mathrm{SH} 3$ domains to bind to proteins with proline-rich motifs, such as the Son of Sevenless guanine nucleotide exchange factor $(3,12-14)$. Besides the guanine nucleotide exchange factors, Grb2 has been demonstrated to use its SH3 domain to bind to other proline-rich containing proteins, including protein kinase A, phosphatidylinositol 3-kinase, and phospholipase C- $\gamma$ (15-17). The activities of Ras, protein kinase A, phosphatidylinositol 3-kinase, and phospholipase $\mathrm{C}-\gamma$ are known to be important for diseases like cancer. These findings strongly indicate that Grb2 plays an essential role in cancer cell signaling. Suppressing the function or expression of Grb2 should interrupt its vital signaling function and may have a therapeutic application in cancer.

Previously we showed that liposomes could enhance the cellular uptake of oligos, including that of the P-ethoxy oligo which is a nuclease-resistant, hydrophobic analog of phosphodiesters (18). P-ethoxy oligo was used because it could be incorporated into liposomes at $>95 \%$ efficiency. We showed that liposome-incorporated P-ethoxy antisense oligo specific for the grb2 mRNA (L-Grb2) selectively inhibited the expression of Grb2 protein and the proliferation of $b c r$ $a b l$-positive leukemia cell lines. Here we determined whether L-Grb2 may be used as a novel therapeutic modality against 
$b c r$-abl-positive leukemia. We studied the pharmacokinetics, the tissue distribution, and the safety of L-Grb2 in normal rodents. We also studied the effects of L-Grb2 on the survival of mice bearing $b c r$-abl-positive leukemia xenografts.

\section{Materials and methods}

Animals, lipids and P-ethoxy oligo. Lewis rats weighing approximately $400 \mathrm{~g}$ and ICR mice weighing 25-30 g were obtained from Harlan Sprague Dawley (Indianapolis, IN, USA). DOPC lipids were purchased from Avanti Polar Lipids (Alabaster, AL, USA). P-ethoxy oligos were purchased from Oligos Etc. (Wilsonville, OR, USA). We previously demonstrated that the Grb2 antisense oligo: 5'-ATATTTGGC GATGGCTTC-3' inhibited Grb2 protein expression, whereas the control oligo: 5'-TCGCCACTCGATCCTGCCCG-3' did not (19-21).

Labeling of Grb2 oligos with $\left[\gamma^{32} P\right]$ ATP. Grb2 antisense oligo was labeled overnight at $37^{\circ} \mathrm{C}$ with $\left[\gamma^{32} \mathrm{P}\right]$ ATP at the $5^{\prime}$ end by $\mathrm{T} 4$ polynucleotide kinase similar to that previously described $(22,23)$. A final $25 \%$ of DMSO (v/v) was included in the labeling reaction to ensure that P-ethoxy oligo remained soluble during the labeling reactions. After the labeling reaction was carried out, oligo was twice filtered through a Microcon-3 filter (Amicon, Beverly, MA, USA) to separate the labeled oligo from free $\left[\gamma^{32} \mathrm{P}\right]$ ATP. Typically, $99 \%$ of the radiolabel was associated with the Grb2 oligo.

Preparation of liposomal oligo. Grb2 antisense or control oligo was incorporated into liposomes composed of DOPC as previously described $(22,23)$. For tissue distribution studies, ${ }^{32} \mathrm{P}$-labeled Grb2 antisense oligo was incorporated into liposomes instead. Liposomal oligo was reconstituted with $0.9 \%$ saline at a final oligo concentration of $40 \mathrm{mg} / \mathrm{ml}$. The mean diameter of the liposomes was $\leq 0.9 \mu \mathrm{m}$ (Nicomp Laser Subparticle Sizer, Santa Monica, CA, USA). The incorporation of P-ethoxy oligo into liposomes was $95 \%$.

Extraction of ${ }^{32} P$-labeled L-Grb2 from whole blood and tissues. ${ }^{32} \mathrm{P}-$ labeled L-Grb2 was extracted from whole blood and tissue samples as described $(22,23)$. Blood and tissue samples were pretreated and decolorized with hyamine hydroxide and $\mathrm{H}_{2} \mathrm{O}_{2}$ according to the manufacturer's protocol (ICN, Costa Mesa, CA, USA). The amount of ${ }^{32} \mathrm{P}$ associated with the samples was then counted by liquid scintillation.

Pharmacokinetics. Lewis rats were anesthetized with sodium thiopental (intraperitoneal injection of $35 \mathrm{mg}$ per $\mathrm{kg}$ of rat body weight). The right femoral artery and left femoral vein were surgically exposed and cannulated. Rats were injected intravenously with $10 \mathrm{mg}$ L-Grb2 per $\mathrm{kg}$ rat body weight, which is in equivalent to $20 \mathrm{mg}$ L-Grb2 per $\mathrm{kg}$ mouse body weight (24). Arterial blood samples of approximately $0.3 \mathrm{ml}$ each were withdrawn at 5, 10, 20,30, 60, 90, 120, 180, and 240 min after injection. After each withdrawal, the catheter was flushed with sodium heparin 1:1000 (units/ml). An aliquot of the injected dose was maintained as a control sample. Whole blood samples were extracted and assayed for ${ }^{32} \mathrm{P}$ radioactivity by liquid scintillation. Pharmacokinetic parameters were determined by nonlinear regression analysis (Rstrip; Micro Math, Inc., Salt Lake City, UT, USA). The data were best fit to a two-compartment model:

$$
\mathrm{C}_{\mathrm{t}}=\mathrm{Ae}^{-\alpha \mathrm{t}}+\mathrm{Be}^{-\beta \mathrm{Bt}}
$$

where $C_{t}$ equals concentration at time $t, A$, and $B$ are the $y-$ axis intercepts, $\alpha$ and $B$ are the constants for distribution and elimination, respectively, and $\mathrm{t}$ is time. $\mathrm{T}_{1 / 2 \alpha}$ and $\mathrm{t}_{1 / 2 \beta}$ were calculated from $\ln 2 / \alpha$ and $\ln 2 / \beta$, respectively. $\mathrm{C}_{0}$ was calculated from the above equation at time zero; therefore, $\mathrm{C}_{0}$ equals $\mathrm{A}+\mathrm{B}$. Vd was calculated as the ratio of initial dose to $\mathrm{C}_{0}$.

Tissue distribution studies. For tissue distribution studies, 20 mice were used and divided into four groups of five mice each. The control group was not injected; mice in the other three groups each received a single injection of $20 \mathrm{mg}{ }^{32} \mathrm{P}$-labeled $\mathrm{L}-\mathrm{Grb} 2 / \mathrm{kg}$ mouse body weight via the tail vein. Mice were then sacrificed by $\mathrm{CO}_{2}$ inhalation at 4,24 or $48 \mathrm{~h}$ post-injection. Organs were dissected and tissue samples (50-100 mg) from each organ were weighed and processed before ${ }^{32} \mathrm{P}$ radioactivity was counted in a scintillation counter $(22,23)$. Results are

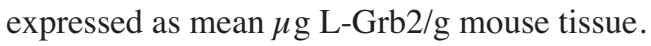

Safety studies. Groups of 5 mice received a single injection of L-Grb2 via the tail vein, while groups of 8 mice received multiple injections of L-Grb2. For single dose studies, mice received $0,15,20,30$, or $40 \mathrm{mg} \mathrm{L-Grb} 2 / \mathrm{kg}$ mouse body weight. In multiple dose studies, mice received a daily single

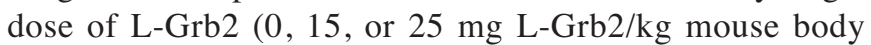
weight) for five consecutive days (for a total of 0,75 , or $125 \mathrm{mg} \mathrm{L}-\mathrm{Grb} 2 / \mathrm{kg}$ mouse body weight). Blood samples, by performing eye bleeds at 2 and 6 weeks post-injection, were analyzed for hematologic parameters, and for renal and hepatic functions. Hematological parameters include RBC counts, hemoglobin, hematocrit, platelet counts, and WBC counts. Creatinine and BUN assays were used to evaluate renal functions. SGOT and alkaline phosphatase assays were performed to test for hepatic functions. After the blood samples were collected at 6 weeks postinjection, the mice were sacrificed by $\mathrm{CO}_{2}$ inhalation and necropsies were performed. Heart, lungs, kidneys, spleen, liver and femurs (for bone marrow) were removed from each mouse and fixed by immersion in $10 \%$ neutral buffered formalin (Fisher Scientific, Houston, TX, USA) immediately after autopsy. Specimens were processed for embedding in paraffin blocks, and sections (2-4 $\mu \mathrm{m})$ were cut and stained with hematoxylin and eosin by the Department of Veterinary Medicine, M.D. Anderson Cancer Center.

Efficacy studies. 32D murine leukemia cells stably expressing the $b c r$ - $a b l$ gene were used (25). NOD/scid mice (kindly provided by L. Schulz, Jackson Laboratories) were bred and maintained under specific pathogen-free conditions in the Barrier Facility within the Center for Comparative Medicine at Baylor College of Medicine. The animal experiments were approved by the Animal Care Committee of the Baylor College of Medicine. $b c r$-abl-positive 32D leukemia cells were inoculated into NOD/scid mice as described (25). Six- to eightweek-old mice were sub-lethally irradiated with $250 \mathrm{cGy}$ 
Table I. Single dose pharmacokinetics of L-Grb2 in Lewis rats.

\begin{tabular}{|c|c|c|c|c|c|c|}
\hline Rat & $\begin{array}{c}\mathrm{Cp}_{0} \\
(\mu \mathrm{g} / \mathrm{ml})\end{array}$ & $\begin{array}{l}\mathrm{Vd} \\
(\mathrm{ml})\end{array}$ & $\begin{array}{c}\mathrm{t}_{1 / 2 \alpha} \\
(\min )\end{array}$ & $\begin{array}{c}\mathrm{t}_{1 / 2 \beta} \\
(\mathrm{min})\end{array}$ & $\begin{array}{c}\text { AUC } \\
(\mu \mathrm{g} / \mathrm{ml} \times \mathrm{min})\end{array}$ & $\begin{array}{c}\mathrm{rt} \\
(\mathrm{min})\end{array}$ \\
\hline 1 & 100 & 34.7 & 4.8 & 240 & 6.5 & 336 \\
\hline 2 & 100 & 34.8 & 5.4 & 216 & 5.8 & 294 \\
\hline 3 & 90 & 36.0 & 5.4 & 216 & 5.0 & 294 \\
\hline 4 & 90 & 37.5 & 5.4 & 216 & 4.2 & 294 \\
\hline 5 & 80 & 39.1 & 4.8 & 240 & 5.4 & 330 \\
\hline Mean \pm SD & $90 \pm 10$ & $36.4 \pm 1.9$ & $5.2 \pm 0.3$ & $225.6 \pm 13.2$ & $5.4 \pm 0.9$ & $309.6 \pm 21.5$ \\
\hline
\end{tabular}

$\mathrm{Cp}_{0}$, maximum concentration at time $0 ; \mathrm{Vd}$, volume of distribution; AUC, area under the concentration curve; rt, residence time.

Table II. Tissue distribution of L-Grb2 in ICR mice. ${ }^{a}$

\begin{tabular}{cccccccc}
\hline \multirow{2}{*}{$\begin{array}{c}\text { Time } \\
\text { (h) }\end{array}$} & Spleen & Liver & Kidney & Heart & Stomach & Lung & Bone marrow $^{\mathrm{c}}$ \\
\cline { 2 - 8 } & & & & & & \\
\hline 4 & $63.9 \pm 3.6$ & $49.9 \pm 8.4$ & $34.0 \pm 6.0$ & $31.5 \pm 6.4$ & $12.2 \pm 4.1$ & $24.5 \pm 5.0$ & $0.4 \pm 0.1$ \\
24 & $30.6 \pm 3.3$ & $21.5 \pm 3.5$ & $19.2 \pm 3.0$ & $12.5 \pm 2.1$ & $6.8 \pm 4.4$ & $17.5 \pm 3.6$ & $0.4 \pm 0.1$ \\
48 & $18.5 \pm 1.9$ & $12.9 \pm 1.3$ & $13.2 \pm 1.1$ & $9.7 \pm 1.0$ & $3.9 \pm 1.9$ & $11.9 \pm 2.0$ & $0.3 \pm 0.1$ \\
\hline
\end{tabular}

${ }^{a}$ Five ICR mice per group were used. ${ }^{b} \mathrm{~L}-\mathrm{Grb} 2$ was expressed as means $\pm \mathrm{SD}$. ${ }^{\mathrm{c}}$ Two femurs were used.

from a 137Cs source (Nordion, Gammacell 40 at approximately $100 \mathrm{cGy}$ per minute) immediately before tail vein injection of $1 \times 10^{6}$ bcr-abl-positive 32D murine leukemia cells. One day after leukemia cell inoculation, mice received twice weekly injections of liposomal oligos via the tail vein. Mice were observed daily for moribundity/morbidity for up to 48 days. Moribund mice were euthanized by $\mathrm{CO}_{2}$ inhalation. In the first experiment, 5 mice were injected with a dose of $15 \mathrm{mg}$ L-Grb2/kg mouse body weight, while 6 mice were injected with an equivalent dose of DOPC (41 mg DOPC/kg mouse body weight). In the second experiment, mice ( 5 mice per group) were injected with 5,10 or $15 \mathrm{mg} \mathrm{L}-\mathrm{Grb} 2 / \mathrm{kg}$ mouse body weight, or with $15 \mathrm{mg}$ liposomal control oligo/kg mouse body weight.

Statistical analysis. Statistical analysis at a p-value of 0.05 was performed according to the methods in Numerical Recipes in FORTRAN: The Art of Scientific Computing. A p-value of $<0.05$ was considered statistically significant.

\section{Results}

Pharmacokinetics. The clearance of L-Grb2 from plasma closely fit a two-compartment mathematical model (correlation $r^{2}>0.98$ ). The initial distribution phase occurred over the first 6 min after injection $\left(t_{1 / 2 \alpha}=5.16 \pm 0.3 \mathrm{~min}\right.$; Table $\left.\mathrm{I}\right)$. The terminal phase half-life $\left(\mathrm{t}_{1 / 2 \beta}\right)$ was $225.6 \pm 13.2 \mathrm{~min}$. The immediate apparent volume of distribution $(36.42 \pm 1.88 \mathrm{ml})$ was higher than the total blood volume for rats of this size, suggesting that L-Grb2 was distributed widely within the body of the rat.

Tissue distribution. L-Grb2 was detected in all the organs examined: spleen, liver, kidneys, heart, lungs, stomach, and bone marrow. At all time points measured (4, 24, and $48 \mathrm{~h}$ ), the highest tissue concentrations of L-Grb2 were detected in the spleen, followed by the liver and kidney (Table II). At $4 \mathrm{~h}$ post-injection, the amount of L-Grb2 detected per $\mathrm{g}$ of tissues was $64 \mu \mathrm{g}$ in spleen, $50 \mu \mathrm{g}$ in liver, $34 \mu \mathrm{g}$ in kidney, and between 12-34 $\mu \mathrm{g}$ in other tissues. The amount of L-Grb2 decreased over time in the various organs examined. By $24 \mathrm{~h}$, the amount of L-Grb2 in spleen, liver and kidney had decreased to $20-30 \mu \mathrm{g} / \mathrm{g}$ tissues, as compared to $7-18 \mu \mathrm{g} / \mathrm{g}$ tissues in the other organs. A much lower amount of L-Grb2 $(\sim 0.4 \mu \mathrm{g}$ in two femurs) was detected in the bone marrow, where it remained relatively constant at all three time points.

Safety studies. Since Grb2 is a ubiquitously expressed protein, inhibition of Grb2 expression by L-Grb2 could cause toxic effects. Thus, we determined the L-Grb2 doses that could be safely administered to mice. We followed the guidelines of the Food and Drug Administration to study the acute and the chronic toxic effects of L-Grb2 in normal mice. The acute and chronic toxicity studies were determined 2 and 6 weeks post-injection, respectively.

At all L-Grb2 doses tested, no evidence of toxicity was observed in the biochemical tests of renal and hepatic functions performed on blood samples collected 2 or 6 weeks post- 
Table III. A single intravenous dose of L-Grb2 did not impair renal and hepatic functions in ICR mice. ${ }^{a}$

\begin{tabular}{lccccc}
\hline $\begin{array}{l}\text { Oligo dose } \\
(\mathrm{mg} / \mathrm{kg})\end{array}$ & $\begin{array}{c}\text { Lipid dose } \\
(\mathrm{mg} / \mathrm{kg})\end{array}$ & $\begin{array}{c}\text { Creatinine } \\
(\mathrm{mg} / \mathrm{dl})\end{array}$ & $\begin{array}{c}\text { BUN } \\
(\mathrm{mg} / \mathrm{dl})\end{array}$ & $\begin{array}{c}\text { SGOT } \\
(\mathrm{IU} / \mathrm{l})\end{array}$ & $\begin{array}{c}\text { Alkaline phosphatase } \\
(\mathrm{IU} / \mathrm{l})\end{array}$ \\
\hline $\begin{array}{l}2 \text { weeks post-injection } \\
0\end{array}$ & 0 & $0.58 \pm 0.05$ & $32.28 \pm 3.88$ & $149.30 \pm 69.22$ & $57.8 \pm 26.32$ \\
15 & 40.5 & $0.68 \pm 0.08$ & $32.88 \pm 1.51$ & $131.20 \pm 55.89$ & $44.0 \pm 29.57$ \\
20 & 54.0 & $0.72 \pm 0.05$ & $29.16 \pm 3.51$ & $92.00 \pm 27.40$ & $18.8 \pm 13.79$ \\
30 & 81.0 & $0.68 \pm 0.05$ & $26.00 \pm 3.70$ & $179.60 \pm 150.90$ & $54.6 \pm 17.84$ \\
40 & 108.0 & $0.58 \pm 0.05$ & $27.86 \pm 3.35$ & $254.80 \pm 150.20$ & $76.8 \pm 71.23$ \\
6 weeks post-injection & & & & $125.9 \pm 108.8$ & $129.2 \pm 56.8$ \\
0 & 0 & $0.55 \pm 0.09$ & $30.44 \pm 2.32$ & $128.6 \pm 41.6$ & $33.8 \pm 27.0$ \\
15 & 40.5 & $0.58 \pm 0.04$ & $27.00 \pm 1.38$ & $137.3 \pm 42.1$ & $49.4 \pm 26.8$ \\
20 & 54.0 & $0.60 \pm 0.00$ & $27.00 \pm 1.77$ & $197.0 \pm 132.6$ & $41.8 \pm 8.3$ \\
30 & 81.0 & $0.55 \pm 0.06$ & $30.20 \pm 5.32$ & $50.2 \pm 37.5$ \\
40 & 108.0 & $0.56 \pm 0.05$ & $28.84 \pm 2.62$ & & \\
\hline
\end{tabular}

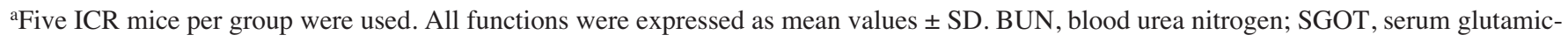
oxaloacetic transaminase.

Table IV. Multiple intravenous doses of L-Grb2 did not impair renal and hepatic functions in ICR mice. ${ }^{\mathrm{a}}$

\begin{tabular}{|c|c|c|c|c|c|}
\hline $\begin{array}{l}\text { Oligo dose } \\
(\mathrm{mg} / \mathrm{kg})\end{array}$ & $\begin{array}{l}\text { Lipid dose } \\
(\mathrm{mg} / \mathrm{kg})\end{array}$ & $\begin{array}{l}\text { Creatinine } \\
(\mathrm{mg} / \mathrm{dl})\end{array}$ & $\begin{array}{c}\text { BUN } \\
(\mathrm{mg} / \mathrm{dl})\end{array}$ & $\begin{array}{l}\text { SGOT } \\
(\mathrm{IU} / 1)\end{array}$ & $\begin{array}{c}\text { Alkaline phosphatase } \\
\text { (IU/1) }\end{array}$ \\
\hline \multicolumn{6}{|c|}{2 weeks post-injection } \\
\hline 0 & 0 & $0.74 \pm 0.05$ & $26.29 \pm 3.19$ & $72.00 \pm 67.64$ & $94.38 \pm 57.36$ \\
\hline 15 & 40.5 & $0.64 \pm 0.05$ & $27.81 \pm 3.37$ & $82.30 \pm 71.90$ & $103.13 \pm 60.64$ \\
\hline 20 & 67.5 & $0.60 \pm 0.05$ & $25.40 \pm 1.36$ & $59.10 \pm 20.45$ & $85.00 \pm 52.79$ \\
\hline \multicolumn{6}{|c|}{6 weeks post-injection } \\
\hline 0 & 0 & $0.60 \pm 0.00$ & $27.25 \pm 1.90$ & $176.75 \pm 173.75$ & $46.88 \pm 21.28$ \\
\hline 15 & 40.5 & $0.60 \pm 0.05$ & $29.95 \pm 4.88$ & $168.13 \pm 92.37$ & $45.25 \pm 38.25$ \\
\hline 25 & 67.5 & $0.58 \pm 0.05$ & $28.64 \pm 1.46$ & $198.25 \pm 172.74$ & $30.75 \pm 15.60$ \\
\hline
\end{tabular}

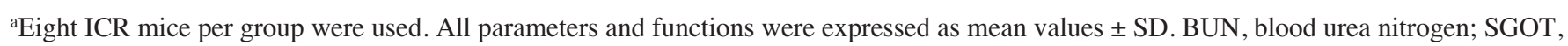
serum glutamic-oxaloacetic transaminase.

injection (Tables III and IV), nor did L-Grb2 affect the production of RBC, hemoglobin, hematocrit or platelets (Tables V and VI).

In the single dose studies, when mice received an L-Grb2 dose of 15 or $20 \mathrm{mg} / \mathrm{kg}$ body weight, their WBC counts were similar to those of untreated mice (Table V). L-Grb2 doses of 30 or $40 \mathrm{mg} / \mathrm{kg}$ body weight resulted in lower WBC counts at 2 weeks post-injection (Table V). At 6 weeks post-injection, the WBC counts in mice that received $30 \mathrm{mg} \mathrm{L}-\mathrm{Grb} 2 / \mathrm{kg}$ body weight returned to normal. The WBC counts of mice that received $40 \mathrm{mg} \mathrm{L}-\mathrm{Grb} 2 / \mathrm{kg}$ body weight remained approximately $30 \%$ lower than the levels of untreated mice (Table V). However, these decreased WBC counts were not statistically different from those of untreated mice $(p=0.31)$.
In the multiple dose studies, mice that received L-Grb2 had WBC counts that were approximately $40 \%$ lower than those of control untreated mice. The lower values for WBC counts occurred as early as 2 weeks post-injection and persisted till 6 weeks post-injection (Table VI). The WBC counts in mice that received a total dose of $75 \mathrm{mg} \mathrm{L}-\mathrm{Grb} 2 / \mathrm{kg}$ body weight were statistically significant from those of untreated mice both at 2 and 6 weeks post-injection; $\mathrm{p}=0.002$, and 0.009 , respectively. Similarly, the WBC counts in mice treated with $125 \mathrm{mg} \mathrm{L}-\mathrm{Grb} 2 / \mathrm{kg}$ body weight were also statistically significant from those of untreated mice at 2 weeks $(\mathrm{p}=0.0007)$ and 6 weeks post-injection $(\mathrm{p}=0.018)$. When the differential WBC counts were examined, the percent of lymphocytes, monocytes and segmented cells was very similar between 
Table V. Effects of a single intravenous dose of L-Grb2 on the hematological parameters in ICR mice. ${ }^{\mathrm{a}}$

\begin{tabular}{|c|c|c|c|c|c|c|}
\hline $\begin{array}{l}\text { Oligo dose } \\
(\mathrm{mg} / \mathrm{kg})\end{array}$ & $\begin{array}{l}\text { Lipid dose } \\
(\mathrm{mg} / \mathrm{kg})\end{array}$ & $\begin{array}{c}\mathrm{RBC} \\
\left(\mathrm{x} 10^{6} / \mu 1\right)\end{array}$ & $\begin{array}{l}\text { Hemoglobin } \\
\qquad(\mathrm{g} / \mathrm{dl})\end{array}$ & $\begin{array}{c}\text { Hematocrit } \\
(\%)\end{array}$ & $\begin{array}{l}\text { Platelets } \\
\left(\mathrm{x} 10^{3} / \mu 1\right)\end{array}$ & $\begin{array}{c}\text { WBC } \\
\left(\times 10^{3} / \mu 1\right)\end{array}$ \\
\hline \multicolumn{7}{|c|}{2 weeks post-injection } \\
\hline 0 & 0 & $8.5 \pm 0.4$ & $14.7 \pm 0.7$ & $41.4 \pm 1.1$ & $1170 \pm 238.5$ & $6.4 \pm 1.8$ \\
\hline 15 & 40.5 & $8.3 \pm 0.3$ & $14.2 \pm 0.5$ & $39.8 \pm 1.2$ & $1302 \pm 176.0$ & $5.0 \pm 0.7$ \\
\hline 20 & 54.0 & $8.6 \pm 0.3$ & $15.0 \pm 0.4$ & $41.7 \pm 0.7$ & $1149 \pm 271.6$ & $5.3 \pm 1.7$ \\
\hline 30 & 81.0 & $8.6 \pm 0.4$ & $14.5 \pm 0.6$ & $40.7 \pm 1.0$ & $1099 \pm 187.1$ & $3.6 \pm 1.2$ \\
\hline 40 & 108.0 & $9.0 \pm 0.2$ & $15.3 \pm 0.3$ & $42.6 \pm 0.9$ & $1147 \pm 266.2$ & $4.5 \pm 1.4$ \\
\hline \multicolumn{7}{|c|}{6 weeks post-injection } \\
\hline 0 & 0 & $8.5 \pm 0.5$ & $14.5 \pm 1.1$ & $40.5 \pm 2.2$ & $1065 \pm 277.4$ & $6.0 \pm 3.0^{\mathrm{b}}$ \\
\hline 15 & 40.5 & $8.7 \pm 0.7$ & $14.5 \pm 1.1$ & $41.1 \pm 2.6$ & $1099 \pm 253.2$ & $9.3 \pm 2.0$ \\
\hline 20 & 54.0 & $8.6 \pm 0.3$ & $14.4 \pm 0.5$ & $40.4 \pm 1.4$ & $976 \pm 232.8$ & $5.7 \pm 2.3$ \\
\hline 30 & 81.0 & $8.5 \pm 0.1$ & $14.3 \pm 0.3$ & $40.2 \pm 0.7$ & $1131 \pm 99.2$ & $6.3 \pm 0.8$ \\
\hline 40 & 108.0 & $9.0 \pm 0.3$ & $15.2 \pm 0.1$ & $42.6 \pm 0.9$ & $1168 \pm 322.7$ & $4.2 \pm 2.3^{\mathrm{b}}$ \\
\hline
\end{tabular}

${ }^{a}$ Five ICR mice per group were used. All parameters and functions were expressed as mean values \pm SD. RBC, red blood cells; WBC, white blood cells. ${ }^{\text {}}$ The number of WBC in mice treated with $40 \mathrm{mg} \mathrm{L}-\mathrm{Grb} 2 / \mathrm{kg}$ body weight was not statistically different to that of untreated mice at 6 weeks postinjection $(\mathrm{p}=0.31)$.

Table VI. Effects of multiple intravenous doses of L-Grb2 on the hematological parameters in ICR mice. ${ }^{\mathrm{a}}$

\begin{tabular}{|c|c|c|c|c|c|c|}
\hline $\begin{array}{l}\text { Oligo dose } \\
(\mathrm{mg} / \mathrm{kg})\end{array}$ & $\begin{array}{l}\text { Lipid dose } \\
\text { (mg/kg) }\end{array}$ & $\begin{array}{c}\mathrm{RBC} \\
\left(\mathrm{x} 10^{6} / \mu 1\right)\end{array}$ & $\begin{array}{l}\text { Hemoglobin } \\
(\mathrm{g} / \mathrm{dl})\end{array}$ & $\begin{array}{c}\text { Hematocrit } \\
(\%)\end{array}$ & $\begin{array}{l}\text { Platelets } \\
\left(\mathrm{x} 10^{3} / \mu 1\right)\end{array}$ & $\begin{array}{c}\mathrm{WBC} \\
\left(\mathrm{x} 10^{3} / \mu \mathrm{l}\right)\end{array}$ \\
\hline \multicolumn{7}{|c|}{2 weeks post-injection } \\
\hline 0 & 0 & $8.6 \pm 0.5$ & $14.9 \pm 0.9$ & $41.6 \pm 2.1$ & $1207 \pm 352.7$ & $8.2 \pm 2.2^{\mathrm{b}, \mathrm{c}}$ \\
\hline 15 & 40.5 & $8.5 \pm 0.4$ & $14.6 \pm 0.9$ & $41.1 \pm 2.3$ & $1072 \pm 187.3$ & $4.9 \pm 1.2^{\mathrm{b}}$ \\
\hline 25 & 67.5 & $8.8 \pm 0.6$ & $15.1 \pm 1.0$ & $42.7 \pm 3.1$ & $1179 \pm 217.8$ & $4.3 \pm 1.2^{\mathrm{c}}$ \\
\hline \multicolumn{7}{|c|}{6 weeks post-injection } \\
\hline 0 & 0 & $8.5 \pm 0.4$ & $15.0 \pm 0.7$ & $40.3 \pm 1.7$ & $1183 \pm 177.9$ & $8.5 \pm 0.4^{\mathrm{d}, \mathrm{c}}$ \\
\hline 15 & 40.5 & $8.4 \pm 0.2$ & $14.9 \pm 0.7$ & $40.1 \pm 1.4$ & $1116 \pm 129.2$ & $4.5 \pm 1.4^{\mathrm{d}}$ \\
\hline 25 & 67.5 & $8.8 \pm 0.5$ & $14.9 \pm 0.6$ & $41.8 \pm 2.3$ & $1083 \pm 219.0$ & $5.0 \pm 1.0^{\mathrm{e}}$ \\
\hline
\end{tabular}

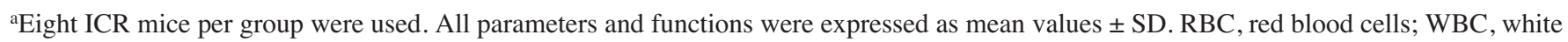
blood cells. ${ }^{b}$ The number of WBC in mice treated with $5 \times 15 \mathrm{mg} \mathrm{L}-\mathrm{Grb} 2 / \mathrm{kg}$ body weight was statistically lower than that of untreated mice at 2 weeks post-injection ( $\mathrm{p}=0.002$ ). ${ }^{\mathrm{c}}$ The number of $\mathrm{WBC}$ in mice treated with $5 \times 25 \mathrm{mg} \mathrm{L}-\mathrm{Grb} 2 / \mathrm{kg}$ body weight was statistically lower than that of untreated mice at 2 weeks post-injection ( $\mathrm{p}=0.0007)$. ${ }^{\mathrm{d}}$ The number of WBC in mice treated with $5 \times 15 \mathrm{mg} \mathrm{L}-\mathrm{Grb} 2 / \mathrm{kg}$ body weight was statistically lower than that of untreated mice at 6 weeks post-injection $(\mathrm{p}=0.009)$. ${ }^{\mathrm{e}}$ The number of WBC in mice treated with $5 \times 25 \mathrm{mg}$ L-Grb2/kg body weight was statistically lower than that of untreated mice at 6 weeks post-injection $(\mathrm{p}=0.018)$.

that of treated and untreated mice (data not shown), suggesting that L-Grb2 reduced the overall number of WBC, but not a specific subpopulation.

Neither single nor multiple administrations of L-Grb2 induced any microscopic lesions or morphological changes in the examined tissues, including the bone marrow (data not shown). Incidental lesions, which are a normal occurrence for this strain of mice, were observed in occasional mice from both treated and untreated groups. These incidental lesions included lymphoid hyperplasia in the spleen, hyperplasia of various lymph nodes, myeloid hyperplasia in the red pulp of the spleen, and multi-focal tubulointerstitial nephritis.

Efficacy studies. In the first study, we determined the effects of L-Grb2 and empty DOPC liposomes (no oligo) on the survival of mice bearing the bcr-abl-positive 32D leukemia xenografts. After tumor inoculation, mice were randomly assigned to the L-Grb2 and the empty liposome groups. L-Grb2 was given at 
A

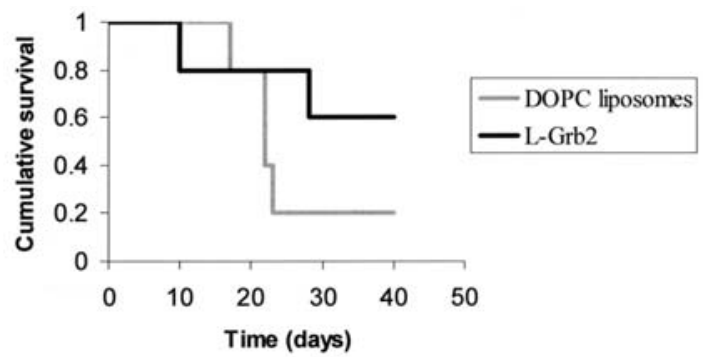

B

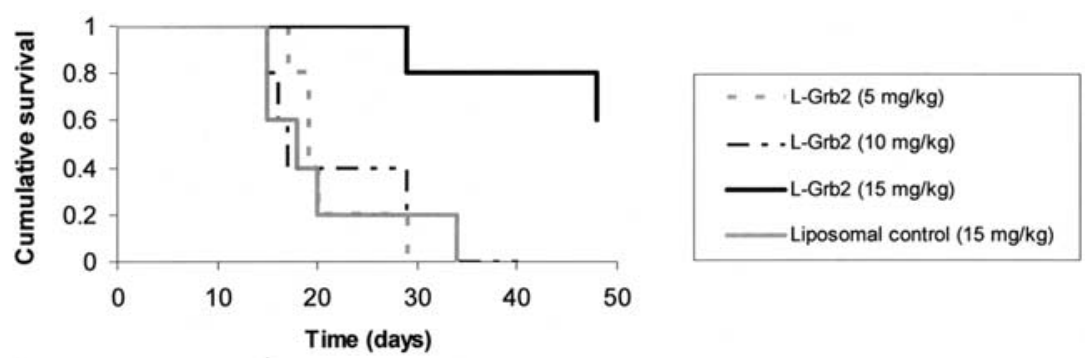

Figure 1. L-Grb2 prolonged the survival of mice bearing $b c r$-abl-positive 32D leukemia xenografts. Six-to eight-week-old NOD/scid mice were sub-lethally irradiated immediately before tail vein injection of $1 \times 10^{6} \mathrm{bcr}$-abl-positive 32D murine leukemia cells. (A) One day after leukemia cell inoculation, mice were divided into two groups. One group of mice ( 5 mice) was injected intravenously with a dose of $15 \mathrm{mg}$ L-Grb2/kg mouse body weight twice weekly. The other group of mice (6 mice) was injected with an equivalent dose of DOPC (41 mg DOPC/kg mouse body weight) twice weekly. Mice were observed daily for moribundity/morbidity for up to 40 days. Moribund mice were euthanized by $\mathrm{CO}_{2}$ inhalation. (B) One day after leukemia cell inoculation, mice were divided into four groups. Mice ( 5 mice per group) were intravenously injected twice weekly with 5,10 or $15 \mathrm{mg} \mathrm{L-Grb} / \mathrm{kg}$ mouse body weight, or with $15 \mathrm{mg}$ liposomal control oligo/kg mouse body weight. Mice were observed daily for moribundity/morbidity for up to 48 days. Moribund mice were euthanized by $\mathrm{CO}_{2}$ inhalation.

an injection dose of $15 \mathrm{mg} / \mathrm{kg}$ mouse body weight, and empty liposomes were given at an equivalent dose $(41 \mathrm{mg} / \mathrm{kg}$ mouse body weight). Mice were observed daily for moribundity/ morbidity. The survival time of these mice after intravenous inoculation of the $b c r$-abl-positive cells varies between 15 and 25 days, and is dependent on the level of $b c r-a b l$ expression (25). All surviving mice were euthanized on day 40. In the group treated with empty liposome, mice started to die on day 17 (Fig. 1A). By day 40, only 1 mouse from that group survived (Fig. 1A). In the group treated with L-Grb2, 1 mouse died during injection on day 10 , and 1 mouse died on day 28; all 3 remaining mice survived to day 40 (Fig. 1A). The mean

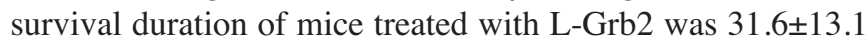
days, and the mean survival of mice treated with empty liposome was $23.7 \pm 8.3$ days (Fig. 1A).

In the second study, we compared the effects of L-Grb2 and liposomal control oligo on the survival of mice bearing the $b c r$-abl-positive 32D leukemia xenografts. After tumor inoculation, mice were randomly assigned to be injected with L-Grb2 or liposomal control oligo. Similar to the first study, liposomal oligo injections were given twice weekly. L-Grb2 was given at a dose of 5,10 , or $15 \mathrm{mg} / \mathrm{kg}$ mouse body weight, whereas liposomal control oligo was given at a dose of $15 \mathrm{mg} /$ $\mathrm{kg}$ mouse body weight. At a dose level of $15 \mathrm{mg} / \mathrm{kg}$ mouse body weight, $80 \%$ of mice treated with L-Grb2 survived to 48 days (end of study), compared to $0 \%$ of mice treated with the same dose of liposomal control oligo (Fig. 1B); in these groups, the mean survival duration was $44.2 \pm 8.5$ versus $20.4 \pm 7.9$ days, respectively. The mean survival duration of mice treated with $5 \mathrm{mg} \mathrm{L}-\mathrm{Grb} 2 / \mathrm{kg}$ mouse body weight was
$20.8 \pm 4.7$ days, whereas the mean survival duration of mice treated with $10 \mathrm{mg} \mathrm{L}-\mathrm{Grb} 2 / \mathrm{kg}$ mouse body weight was 22.2 \pm 8.7 days, respectively (Fig. 1B). These data indicate that L-Grb2 could increase the survival of mice bearing $b c r$ $a b l$-positive leukemia xenografts.

\section{Discussion}

Intravenous injection of NOD/scid mice preconditioned by sub-lethal radiation with $b c r$-abl-positive $32 \mathrm{D}$ mouse cells was demonstrated to cause a lethal leukemia syndrome involving marrow and spleen tissues (25). Pathology studies of spleen and marrow revealed that $b c r$-abl-positive $32 \mathrm{D}$ cells induced vigorous infiltration of tumor cells into spleen and marrow (25). The survival time of these mice after intravenous inoculation of the $b c r$-abl-positive 32D cells varies between 15 and 25 days (25). Using this animal model, we showed in two separate experiments that L-Grb2, administered twice weekly at $15 \mathrm{mg}$ / $\mathrm{kg}$ body weight, increased the survival of mice bearing the bcr-abl-positive 32D leukemia xenografts; the survival of such mice ranged between 32 to 44 days. The enhancement in mouse survival was specific to L-Grb2 as equivalent doses of control empty liposome and liposomal control oligo did not increase mouse survival.

The availability of L-Grb2 to tissues infiltrated with leukemia such as the spleen and the bone marrow most likely contributed to its anti-leukemic effect. Four hours after a single injection dose of $20 \mathrm{mg} \mathrm{L}-\mathrm{Grb} 2 / \mathrm{kg}$ mouse body weight (which is equivalent to $500 \mu \mathrm{g} \mathrm{L}-\mathrm{Grb} 2$ in a $25-\mathrm{g}$ mouse), $6.4 \mu \mathrm{g} \mathrm{L}-\mathrm{Grb} 2$ was found in the spleen (which is approximately 
$0.1 \mathrm{~g}$ for a 25 -g mouse). This high dose of accumulation approximates $1.3 \%$ of the injected L-Grb2 dose. The level of L-Grb2 remained constant over the 48-h period of study. This long half-life of L-Grb2 could allow L-Grb2 to have a significant effect in the marrow even though a much lower amount of L-Grb2 was detected in the marrow.

The tissue distribution, pharmacokinetics, and safety data of L-Grb2 were very similar to those of other liposomeincorporated P-ethoxy oligo that we had previously investigated $(22,23)$. L-Grb2 was distributed widely in the body. The area under the curve of L-Grb2 reflects a two-compartment model of distribution with a biphasic plasma clearance. At all the doses tested, L-Grb2 did not induce any changes in the biochemical functions of the kidney and the liver. L-Grb2 also did not induce any changes in the hematological parameters. However, mice that received a total of at least $75 \mathrm{mg} \mathrm{L-Grb2/}$ $\mathrm{kg}$ body weight, had approximately $40 \%$ lower WBC counts than those of untreated mice. We do not believe that this abnormality is attributable to the DOPC lipid or the P-ethoxy oligo that make up L-Grb2. This is because previously when we administered similar doses of liposome-incorporated Pethoxy antisense oligo targeting either the $b c r-a b l$ or the $b c l-2$ mRNA in the same strain of mice, no WBC reduction or other adverse effect was observed $(22,23)$.

Since histopathologic examination did not show any morphological changes in the bone marrow, we speculate that L-Grb2 disrupted signaling pathways that are crucial in maintaining WBC homeostasis. This may be because Grb2 is critical for Ras signaling, which was found to be vital for the formation of granulocyte/macrophage colonies isolated from human marrow cells. L-Grb2 did not inhibit RBC production, probably because the proliferation and differentiation of $\mathrm{RBC}$ progenitors is independent of Grb2 (28). We did not observe any effects of L-Grb2 on platelet production. This finding is in contrast with that of Skorski et al (29), who showed that inhibition of Ras expression decreased the formation of megakaryocytic colonies. It appears that inhibition of Grb2 may induce similar or less adverse events than inhibition of Ras. The phase I clinical trial of a Ras antisense oligo showed that it was well tolerated with minimal side effects (30). So we expect L-Grb2 to be well tolerated as well.

In summary, we report the novel findings that L-Grb2 prolonged the survival of mice bearing bcr-abl-positive 32D leukemia xenografts. L-Grb2 could be used as a novel cancer therapeutic modality.

\section{Acknowledgments}

This study was supported in part by The Leukemia and Lymphoma Society (to A.M.T.) and by InterPath Pharmaceuticals, Inc. Dr Ana Tari and Dr Gabriel Lopez-Berestein held stock options of InterPath Pharmaceuticals, Inc.

\section{References}

1. Buday L and Downward J: Epidermal growth factor regulates p21ras through the formation of a complex of receptor, Grb2 adapter protein and Sos nucleotide exchange factor. Cell 73: 611-620, 1993.

2. Buday L and Downward J: Epidermal growth factor regulates the exchange rate of guanine nucleotides on p21ras in fibroblasts. Mol Cell Biol 13: 1903-1910, 1993.
3. Chardin P, Camonis J, Gale N, et al: Human Sos1: a guanine nucleotide exchange factor for Ras that binds to GRB2. Science 260: 1338-1343, 1993.

4. Gale NW, Kaplan S, Lowenstein EJ, Schlessinger J and Bar-Sagi D: Grb2 mediates the EGF-dependent activation of guanine nucleotide exchange on Ras. Nature 363: 88-92, 1993.

5. Downward J: Control of Ras activation. In: Cancer Surveys: Cell Signalling. Parker P and Pawson T (eds). Vol. 27. Cold Spring Harbor Laboratory Press, New York, pp87-100, 1996.

6. Pawson T: Protein modules and signalling networks. Nature 373: 573-580, 1995.

7. Schlessinger J and Ullrich A: Growth factor signaling by receptor tyrosine kinases. Neuron 9: 383-391, 1992.

8. Pendergast A, Quilliam L, Cripe L, et al: BCR-ABL-induced oncogenesis is mediated by direct interaction with the $\mathrm{SH} 2$ domain of the GRB-2 adaptor protein. Cell 75: 175-185, 1993.

9. Puil L, Liu J, Gish G, et al: Bcr-Abl oncoproteins bind directly to activators of the ras signalling pathway. EMBO J 13: 764-773, 1994.

10. Lowenstein E, Daly R, Batzer A, et al: The $\mathrm{SH} 2$ and $\mathrm{SH} 3$ domain-containing protein GRB2 links receptor tyrosine kinases to ras signaling. Cell 70: 431-442, 1992.

11. Xie Y, Pendergast A and Hung M-C: Dominant-negative mutants of Grb2 induced reversal of the transformed phenotypes caused by the point mutation-activated rat HER-2/Neu. J Biol Chem 270: 30717-30724, 1995.

12. Egan S, Giddings B, Brooks M, Buday L, Sizeland A and Weinberg R: Association of Sos Ras exchange protein with Grb2 is implicated in tyrosine kinase signal transduction and transformation. Nature 363: 45-51, 1993.

13. Olivier J, Raabe T, Henkemeyer M, et al: A Drosophila SH2$\mathrm{SH} 3$ adaptor protein implicated in coupling the Sevenless tyrosine kinase to an activator of Ras guanine nucleotide exchange, Sos. Cell 73: 179-191, 1993.

14. Simon M, Bowtell D, Dodson G, Laverty T and Rubin G: Ras1 and a putative guanine nucleotide exchange factor perform crucial steps in signaling by the sevenless protein tyrosine kinase. Cell 67: 701-716,1991.

15. Tortora G, Damiano V, Bianco C, et al: The RIa subunit of protein kinase A (PKA) binds to Grb2 and allows PKA interaction with the activated EGF-receptor. Oncogene 14: 923-928, 1997.

16. Wang J, Auger K, Jarvis L, Shi Y and Roberts T: Direct association of Grb2 with the p85 subunit of phosphatidylinositol 3-kinase. J Biol Chem 270: 12774-12780, 1995.

17. Pei Z, Maloney J, Yang L and Williamson JR: A new function for Phospholipase $\mathrm{C}-\gamma 1$ : coupling to the adaptor protein GRB2. Arch Biochem Biophys 345: 103-110, 1997.

18. Tari AM: Preparation and application of liposome-incorporated antisense oligonucleotides. Methods Enzymol 313: 372-388, 2000 .

19. Tari AM, Arlinghaus R and Lopez-Berestein G: Inhibition of Grb2 and Crkl proteins results in growth inhibition of Philadelphia chromosome positive leukemic cells. Biochem Biophys Res Commun 235: 383-388, 1997.

20. Tari AM, Hung M-C, Li K and Lopez-Berestein G: Growth inhibition of breast cancer cells by Grb2 downregulation is correlated with inactivation of mitogen-activated protein kinase in EGFR, but not in ErbB2, cells. Oncogene 18: 1325-1332, 1999.

21. Lim S-J, Lopez-Berestein G, Hung M-C, Lupu R and Tari A: Grb2 downregulation leads to Akt inactivation in heregulinstimulated and ErbB2-overexpressing breast cancer cells. Oncogene 19: 6271-6276, 2000.

22. Tari AM, Stephens C, Rosenblum M and Lopez-Berestein G: Pharmacokinetics, tissue distribution, and safety of P-ethoxy oligonucleotides incorporated in liposomes. J Liposome Res 8: 251-264, 1998.

23. Gutierrez-Puente Y, Tari AM, Stephens C, Rosenblum M, Reyes T and Lopez-Berestein G: Safety, pharmacokinetics, and tissue distribution of liposomal P-ethoxy antisense oligonucleotides targeted to Bcl-2. J Pharmacol Exp Ther 291: 865-869, 1999.

24. Freireich EJ, Gehan EA, Rall DP, Schmidt LH and Skipper HE: Quantitative comparison of toxicity of anticancer agents in mouse, rat, hamster, dog, monkey, and man. Cancer Chemother Rep 50: 219-244, 1966.

25. Lin H, Monaco G, Sun T, et al: Bcr-Abl-mediated suppression of normal hematopoiesis in leukemia. Oncogene 24: 3246-3256, 2005 . 
26. Dazzi F, Capelli D, Hasserjian R, et al: The kinetics and extent of engraftment of chronic myelogenous leukemia cells in nonobese diabetic/severe combined immunodeficiency mice reflect the phase of the donor's disease: an in vivo model of chronic myelogenous leukemia biology. Blood 92: 1390-1396, 1998.

27. Lewis ID, McDiarmid LA, Samels LM, To LB and Hughes TP: Establishment of a reproducible model of chronic-phase chronic myeloid leukemia in NOD/SCID mice using blood-derived mononuclear or CD34+ cells. Blood 91: 630-640, 1998.
28. Klingmuller U, Wu H, Hsiao J, et al: Identification of a novel pathway important for proliferation and differentiation of primary erythroid progenitors. Proc Natl Acad Sci USA 94: 3016-3021, 1997.

29. Skorski T, Szczylik C, Ratajczak M, Malaguarnera L, Gewirtz A and Calabretta B: Growth factor-dependent inhibition of normal hematopoiesis by N-ras antisense oligodeoxynucleotides. J Exp Med 175: 743-750, 1992

30. Cunningham C, Holmlund J, Geary R, et al: A Phase I trial of $\mathrm{H}$-ras antisense oligonucleotide ISIS 2503 administered as a continuous intravenous infusion in patients with advanced carcinoma. Cancer 92: 1265-1271, 2001. 